\title{
Clinical spectrum of biopsy-defined celiac disease in the elderly
}

\author{
HUGH J FREEMAN MD
}

\begin{abstract}
HJ FREEMAN. Clinical spectrum of biopsy-defined celiac disease in the elderly. Can J Gastroenterol 1995;9(1):42-46. Thirty patients (17 females and 13 males) with adult celiac disease initially diagnosed after age 60 were seen during a 12 -year period. Diagnosis in each patient was based on small intestinal biopsy and a clinical as well as histological response to a strict gluten-free diet. Diarrhea, weight loss and/or anemia, usually due to iron deficiency, were present in the majority of patients and often lead to other diagnostic considerations, including colon cancer, prior to definition of celiac disease. No patient in this series had a known family history of celiac disease. Dermatitis herpetiformis and thyroid hypofunction were frequently detected in this elderly population, possibly reflecting the autoimmune and systemic nature of celiac disease. Neoplastic disease was common in this age group, suggesting that particular vigilance in follow-up is required, especially for lymphoma, in elderly patients with celiac disease.
\end{abstract}

Key Words: Ageing, Celiac disease, Dermatitis herpetiformis, Intestinal lymphoma, Lymphocytic colitis, Lymphocytic gastritis, Small intestinal biopsy

Spectre clinique de la maladie caeliaque identifiée par biopsie chez la personne âgée

RÉSUMÉ : Trente patients adultes ( 17 femmes et 13 hommes) souffrant de sprue diagnostiquée après l'âge de 60 ans ont été suivis sur une période de 12 ans. Le diagnostic de chaque patient se fondait sur une biopsie de l'intestin grêle et sur la réponse tant clinique qu'histologique à un régime alimentaire strict sans gluten. La diarrhée, la perte de poids et/ou l'anémie, habituellement attribuables à une carence en fer, s'observaient chez la majorité des patients et entraînaient souvent d'autres considérations diagnostiques, y compris le cancer du côlon, avant que ne soit confirmé le diagnostic de maladie caeliaque. La dermatite herpétiforme et l'hypothyroïdie ont fréquemment été décelées chez cette population âgée, reflétant ainsi possiblement la nature auto-immune et systémique de la maladie caeliaque. La néoplasie a été observée fréquemment dans ce groupe d'âge, ce qui exige une attention particulière au moment du suivi, particulièrement pour ce qui est du lymphome, chez les patients âgés atteints de maladie caeliaque.

Department of Medicine (Gastroenterology), University of British Columbia, Vancouver, British Columbia

Correspondence and reprints: Dr Hugh J Freeman, Gastroenterology, ACU F-137, University Hospital (UBC Site), 2211 Wesbrook Mall, Vancouver, British Columbia V6T 1W5. Telephone (604) 822-7216

Received for publication May 20, 1994. Accepted May 23, 1994
ELIAC DISEASE HAS TRADItionally
been considered a disease of childhood and young adults (1). However, in recent years celiac disease increasingly has been recognized in elderly adults. This changing pattern in the age of initial detection of celiac disease is reflected historically in various series of patients with this disorder. In earlier studies from Birmingham $(1,2)$, for example, only $7 \%$ were diagnosed after age 60 , similar to a Mayo Clinic series of 4\% (3). In more recent reports, however, increasing numbers of elderly patients have been described, especially from some hospitals in the United Kingdom; for example, about 25\% of patients from Northwick Park and St Bartholomew's Hospitals are now being diagnosed in their seventh decade $(2,4)$. Similar observations have been published from the United States (5), Sweden (6), Scotland (7) and Ireland (8). In these reports, classical or typical symptoms of malabsorption have been less prominent even though adult celiac disease is reported to be the most common cause of steatorrhea after age 50 (9).

The purposes of this study are to review a clinical experience of celiac disease in 30 patients diagnosed after age 60 in a single institution and to categorize the spectrum of associated clinical conditions, including malignant complications, seen in this elderly population. 


\section{PATIENTS AND METHODS}

During a 12-year period from January 1982 to December 1993 inclusive, 88 patients were seen with celiac disease; of these, 30 were initially diagnosed during or after their seventh decade at the University of British Columbia Hospital, Vancouver, British Columbia. All except three patients were regularly followed and reviewed on an annual basis in an adult celiac disease clinic, first established in 1982. One of these three patients died from pneumonia six months after the initial diagnosis while the two others died from metastatic ovarian and breast carcinoma, respectively, four and nine months after the initial diagnosis of celiac disease. Four other patients, each followed for over one year, died from lymphoma during the past 12 years, including two patients previously reported elsewhere $(10,11)$. Finally, one patient died from a duodenal adenocarcinoma. Office and hospital records of all patients were reviewed. Details of clinical presentation and past medical history were recorded as well as hematological (hemoglobin, white blood cell count, platelet count, peripheral blood smear) and biochemical results (carotene, iron and iron binding capacity, folic acid, vitamin $\mathrm{B}_{12}$, calcium, phosphate, total protein, albumin, prothrombin time, immunoglobulin quantitation, amylase, and thyroid and liver chemistry tests). After biopsies of the small intestine were done, patients were reviewed by a clinical dietitian with a special interest in the dietary treatment of celiac disease who provided specific instructions on the gluten-free diet. Patients were reviewed periodically, as required, to address any concerns regarding diet treatment. Compliance and response to a prescribed strict gluten-free diet were assessed during each clinic visit. Interestingly, none of the patients reported a known family history of celiac disease.

Diagnosis: Each of the 30 patients in this study had a severely abnormal 'flat' small intestinal biopsy (so-called 'crypt hyperplastic villous atrophy') obtained prior to institution of a gluten-free diet (12). In 29 patients, initial biopsies

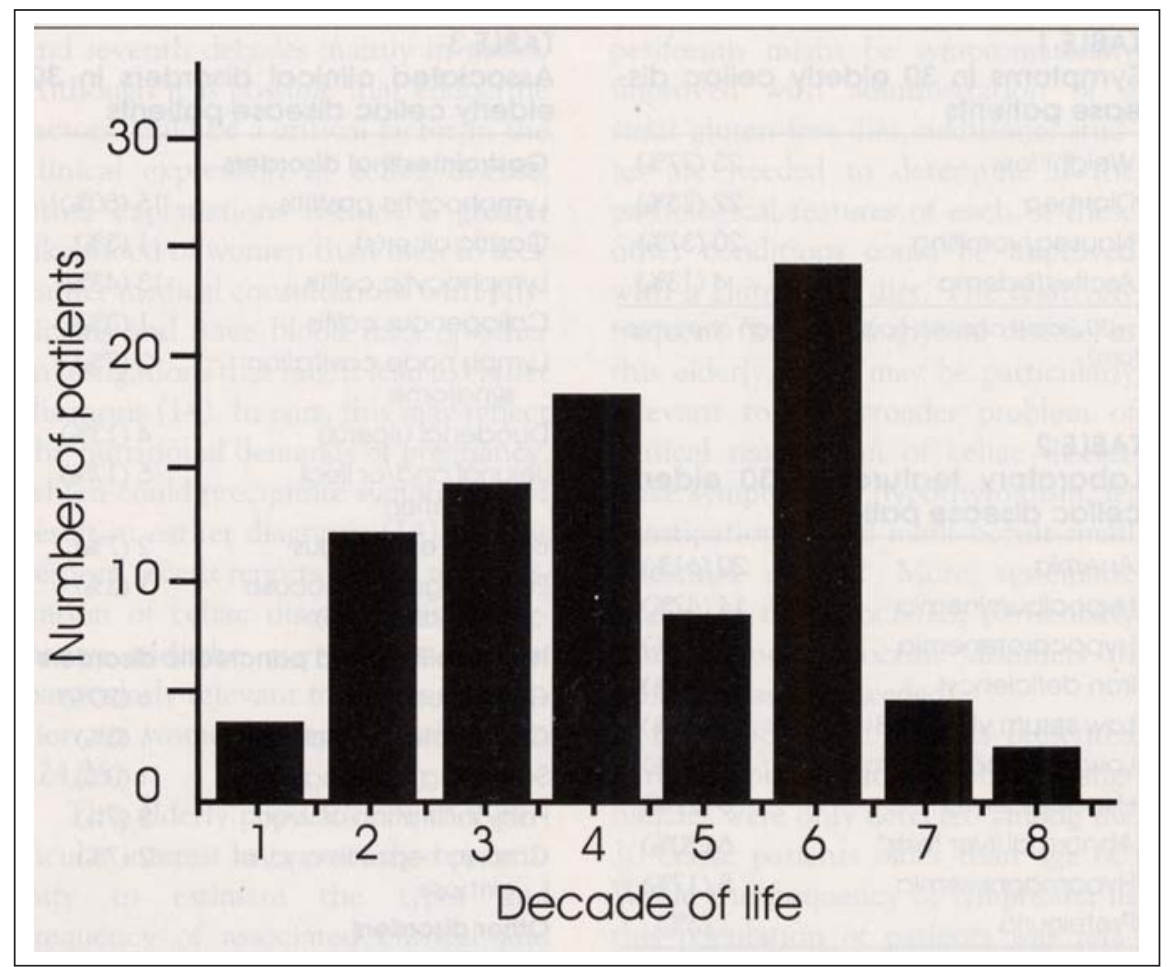

Figure 1) Number of celiac disease patients $(n=88)$ by age. 1 Patients less than 20 years of age; 2 Age 20 to 29 years; 330 to 39 years; 440 to 49 years; 550 to 59 years; 660 to 69 years; 770 to 79 years; 880 years and older

were severely abnormal and treatment was initiated within two weeks. In the one other patient with small bowel lymphoma, previously reported elsewhere (10), multiple small intestinal biopsies on a high gluten diet were required to demonstrate the typical histological features of celiac disease, ie, severely abnormal 'flat' biopsies. Biopsies from at least two separate sites in the small intestine in each patient were obtained with at least one biopsy from a site distal to the descending duodenum. Biopsies were also obtained from the gastric mucosa, usually the anatomical prepyloric gastric antrum, lesser curvature. Finally, in all patients, at least one colorectal mucosal biopsy was obtained, usually from a valve in the distal $25 \mathrm{~cm}$, using either a fibreoptic flexible sigmoidoscope or colonoscope. In 29 patients, biopsies of the small intestine were repeated after at least eight weeks to determine if a histological response to a gluten-free diet had occurred. In the one other patient with a small bowel adenocarcinoma (13), biopsies were repeated after hospitalization for six weeks on a gluten-free diet in a clinical investigation unit setting to ensure compliance. Clinical response to the gluten-free diet was evaluated along with repeated measurements of hematological and biochemical tests in all patients (see above). In most patients, multiple small intestinal biopsies were obtained; in one previously reported patient (11), 88 small intestinal mucosal biopsies were evaluated.

\section{RESULTS}

Age and sex distribution: The age of all patients seen over a 12-year period by the author at the University Hospital is shown in Figure 1. There were 88 adult celiac disease patients (over age 16), with the disease defined in each patient by small intestinal biopsy and response to a gluten-free diet. Altogether there were 64 females and 24 males with a resultant female:male ratio of 2.7:1. These findings are similar to the age and sex distribution for celiac disease patients reported elsewhere $(1,14)$.

Figure 1 also shows the 30 patients evaluated in this study who were 60 years of age or older ( 17 females and 13 males, female:male ratio of 1.3:1). 
TABLE 1

Symptoms in 30 elderly celiac disease patients

\begin{tabular}{lr}
\hline Weight loss & $23(77 \%)$ \\
Diarrhea & $22(73 \%)$ \\
Nausea/vomiting & $20(37 \%)$ \\
Ascites/edema & $4(13 \%)$ \\
\hline $\mathrm{n}=30$ (some patients had more than one symp- \\
tom)
\end{tabular}

TABLE 2

Laboratory features in 30 elderly celiac disease patients

\begin{tabular}{lc}
\hline Anemia & 20 (61\%) \\
Hypoalbuminemia & $14(47 \%)$ \\
Hypocarotenemia & $14(47 \%)$ \\
Iron deficiency & $12(40 \%)$ \\
Low serum vitamin $B_{12}$ & $11(37 \%)$ \\
Low red blood cell folate & $9(30 \%)$ \\
Hypocalcemia & $8(27 \%)$ \\
Abnormal liver tests* & $6(20 \%)$ \\
Hypomagnesemia & $5(17 \%)$ \\
Proteinuria & $1(3 \%)$ \\
\hline $\mathrm{n}=30$ (some patients had more than one symp- \\
$\begin{array}{l}\text { tom); *Tests include alanine aminotransferase, as- } \\
\text { partate aminotransferase and alkaline } \\
\text { phosphatase }\end{array}$
\end{tabular}

TABLE 4

Malignancy in elderly celiac disease patients

\begin{tabular}{ll}
\hline Lymphoma of small bowel & $5(17 \%)$ \\
$\begin{array}{l}\text { Extra-intestinal nodal } \\
\text { lymphoma* }\end{array}$ & $3(10 \%)$ \\
$\begin{array}{l}\text { Small bowel } \\
\quad \text { adenocarcinoma }\end{array}$ & $2(7 \%)$ \\
Gynecological malignancy & $2(7 \%)$ \\
Skin cancer & $2(7 \%)$ \\
\hline
\end{tabular}

$\mathrm{n}=30$ (some patients had more than one type of malignancy); *Sites include tonsillar, inguinal and cervical nodes

These findings are similar to the reported age and sex distribution of celiac disease in elderly patients detailed elsewhere $(4,14)$. In the present series, there were also four females and four males initially diagnosed over age 70 with a resulting female:male ratio in this age group of $1: 1$. This apparent shift in sex distribution with increasing age from a predominantly female disease to a more equivalent sex distribution has been previously reported $(4,14)$.

Patient symptoms: Most, but not all, patients in this study had gastrointesti-
TABLE 3

Associated clinical disorders in 30 elderly celiac disease patients

\begin{tabular}{|c|c|}
\hline \multicolumn{2}{|l|}{ Gastrointestinal disorders } \\
\hline Lymphocytic gastritis & $\begin{array}{l}1 \\
5(50 \%)\end{array}$ \\
\hline Gastric ulcer(s) & $1(3 \%)$ \\
\hline Lymphocytic colitis & $\begin{array}{l}1 \\
3(43 \%)\end{array}$ \\
\hline Collagenous colitis & $1(3 \%)$ \\
\hline $\begin{array}{l}\text { Lymph node cavitation } \\
\text { syndrome }\end{array}$ & $2(7 \%)$ \\
\hline Duodenal ulcer(s) & $4(13 \%)$ \\
\hline $\begin{array}{l}\text { Jejunal and/or ileal } \\
\text { ulceration* }\end{array}$ & $5(17 \%)$ \\
\hline Barrett's esophagus & $2(7 \%)$ \\
\hline $\begin{array}{l}\text { Ectopic gastric mucosa } \\
\quad \text { (in small bowel) }\end{array}$ & $1(3 \%)$ \\
\hline \multicolumn{2}{|c|}{ Hepatobiliary and pancreatic disorders } \\
\hline Gallstones & $6(20 \%)$ \\
\hline Calcification of pancreas & $1(3 \%)$ \\
\hline Sclerosing cholangitis & $1(3 \%)$ \\
\hline Fatty infiltration of liver & $2(7 \%)$ \\
\hline $\begin{array}{l}\text { Chronic hepatitis and/or } \\
\text { cirrhosis }\end{array}$ & $2(7 \%)$ \\
\hline \multicolumn{2}{|l|}{ Other disorders } \\
\hline Dermatitis herpetiformis & $9(30 \%)$ \\
\hline $\begin{array}{l}\text { Hypothyroidism } \\
\text { (Hashimoto's thyroiditis) }\end{array}$ & $8(27 \%)$ \\
\hline $\begin{array}{l}\text { Diabetes mellitus (insulin- } \\
\text { dependent) }\end{array}$ & $1(3 \%)$ \\
\hline $\begin{array}{l}\text { Hyposplenism (splenic } \\
\text { atrophy) }\end{array}$ & $4(13 \%)$ \\
\hline Arthritis & $2(7 \%)$ \\
\hline Kidney stones & $1(3 \%)$ \\
\hline
\end{tabular}

$\mathrm{n}=30$ (some patients had more than one associated condition); *Three of five were small intestinal lymphomas

nal symptoms, usually weight loss and/ or diarrhea, or abnormal blood tests that resulted in gastrointestinal studies (eg, iron deficiency anemia); this differs from a previous series of elderly celiac disease patients (14) that included recruited patients with dermatitis herpetiformis without gastrointestinal symptoms. Table 1 lists the main symptoms seen in this elderly population. In some, multiple symptoms were present, with the most common combination being weight loss and diarrhea, each present in more than $70 \%$ of the 30 patients.

Laboratory investigations: Laboratory test abnormalities in these 30 elderly celiac disease patients and the frequency of each abnormality on the initial evaluation before institution of a gluten-free diet are listed in Table 2. Most often anemia was present, and this was usually associated with iron deficiency. In most patients, these abnormal laboratory tests became completely normal within the subsequent 24 months.

Associated clinical disorders: Associated clinical and pathological features seen in this elderly group of 30 celiac disease patients are outlined in Table 3 . Lymphocytic gastritis (15) and lymphocytic colitis (16) were the most commonly recognized gastrointestinal findings. Collagenous colitis, however, was detected in only one patient $(17,18)$. Small bowel ulceration, either in the duodenum or more distally in the jejunum and/or ileum, were also common. Jejunal and ileal ulceration were usually associated with small intestinal lymphomas. Hepatobiliary tract and pancreatic disorders were also seen; some of these were quite unusual, including pancreatic calcification and sclerosing cholangitis, and have been reported in more detail elsewhere $(19,20)$. Other nongastrointestinal disorders were also present. For example, dermatitis herpetiformis and hematological features of hyposplenism and splenic atrophy were frequently recognized. Hypothyroidism, presumably due to autoimmune thyroiditis (ie, Hashimoto's thyroiditis), was also quite common. It was detected in eight of 30 patients, in some of whom diarrhea was not a clinical feature. In contrast, insulin-dependent diabetes, reported elsewhere to be increased in frequency in patients with celiac disease (21), was distinctly uncommon, being present in only a single patient.

Malignant complications: Table 4 lists the malignant complications observed in this group of 30 patients. Some had more than one site or type of involvement. Most common were lymphomas, either in the small intestine or extra-intestinal nodal lymphomas, including involvement of tonsillar, inguinal or cervical nodes. As described in other reports (22), small bowel adenocarcinoma was also seen in two of the patients in this series. Although increased esophageal carcinoma has been described (23), no patient was seen in the present study and, indeed, only two patients had Barrett's type mucosa 
detected in the distal esophagus, a recognized preneoplastic esophageal lesion.

\section{DISCUSSION}

In a single institution over a 12-year period, over one-third of all patients (34.1\%) diagnosed with celiac disease were older than age 60 . Although this experience could be due to the presence of a more elderly patient referral population in British Columbia, it most likely reflects a local difference in diagnostic enthusiasm and diagnostic acuity - specifically for celiac disease since most of these patients were usually referred for assessment of longstanding diarrhea and/or weight loss after several investigations had already been completed. Variations in detection of celiac disease at a hospital level have been previously reported (4) and it is seems likely that this might be exaggerated in an elderly patient population with other more common diagnostic considerations such as an altered bowel habit, weight loss and/ or iron deficiency anemia (eg, colon cancer).

The apparent shift in the sex distribution from female to male patients was an intriguing observation in this study but has been previously noted in a study by Swinson et al (4) who demonstrated a bimodal distribution with a peak in the fourth decade mainly in females, and a later peak in the sixth and

\section{REFERENCES}

1. Cooke WT, Holmes GKT. Definition and epidemiology. In: Coeliac Disease. Edinburgh: Churchill Livingstone, 1984:11-22.

2. Anonymous. Coeliac disease in the elderly. Lancet 1984;i:775-6. (Edit)

3. Green PA, Wollaeger EE. The clinical behavior of sprue in the United States. Gastroenterology 1960;38:399-418.

4. Swinson CM, Levi AJ. Is coeliac disease underdiagnosed? Br Med J 1980;281:1258-60.

5. Mann JG, Brown WR, Kern F. The subtle and variable clinical expressions of gluten-induced enteropathy (adult celiac disease, nontropical sprue). Am J Med 1970;48:357-66.

6. Hallert C, Gotthard K, Norrby K, Walan A. On the prevalence of adult coeliac disease in Sweden. Scand J Gastroenterol 1981;16:257-61. seventh decades mainly in males. Although it is possible that endocrine factors could be a critical factor in the clinical expression of celiac disease, other explanations include a greater likelihood of women than men to seek earlier medical consultations with physicians and have blood tests or other investigations that might lead to earlier diagnosis (14). In part, this may reflect the nutritional demands of pregnancy, which could precipitate symptoms and result in earlier diagnosis (14). In this respect, recent reports related to reactivation of celiac disease during pregnancy and the puerperium may be particularly relevant to earlier recognition in women compared with men $(24,25)$.

This elderly population was of particular interest because of the opportunity to estimate the types and frequency of associated clinical and pathological disorders emerging in this group and previously reported in celiac disease. In this series, the most commonly detected histological findings were lymphocytic infiltrates in other gastrointestinal epithelial sites, ie, lymphocytic gastritis and colitis $(15,16)$ as well as other immune-mediated clinical conditions in celiac disease known to be associated with lymphocytic infiltrates in the skin and thyroid, including dermatitis herpetiformis and thyroiditis with hypothyroidism. Although there is some evidence that der-

7. Rifkind EA, Logan RFA, Busuttil A, Gilmour H, Ferguson A. Coeliac disease in Edinburgh and the Lothians 1900-80. Scott Med J 1982;27:256.

8. Kirby J, Fielding JF. Very adult coeliac disease! The need for jejunal biopsy in the middle aged and elderly. Ir Med J 1984;77:35-6.

9. Price HL, Gazzard BG, Dawson AM. Steatorrhea in the elderly. Br Med J 1977;1:1582-4.

10. Freeman HJ, Chiu BK. Multifocal small bowel lymphoma and latent celiac sprue. Gastroenterology 1986;90:1992-7.

11. Freeman HJ, Chiu BK. Small bowel lymphoma complicating celiac sprue and the mesenteric lymph node cavitation syndrome. Gastroenterology 1986;90:2008-12.

12. Freeman HJ. Celiac disease. Contemp Gastroenterol 1993;1:6-9. matitis herpetiformis might be symptomatically improved with administration of a strict gluten-free diet, additional studies are needed to determine if the pathological features of each of these other conditions could be improved with a gluten-free diet. The relatively frequent finding of thyroid disease in this elderly group may be particularly relevant to the broader problem of clinical recognition of celiac disease since symptoms of hypothyroidism, ie, constipation, could mask occult small intestinal disease. More systematic studies of the associated, particularly autoimmune, endocrine disorders in celiac disease are needed.

In all 88 celiac patients presented here, lymphoma and/or other malignancies were only detected among the 30 celiac patients older than age 60 . While the frequency of lymphoma in this population of patients was relatively high, this likely reflected, in part, the problem of referral bias. In some patients, referral with a diagnosed or suspected lymphoma was made and celiac disease was only detected later in the clinical course. While lymphoma may be diagnosed in celiac disease patients before age 60 , this appears to be less common (26). Thus, particular vigilance and careful follow-up for a neoplastic complication is very critical in elderly celiac patients, even if the diagnosis is initially established late in their clinical course.

13. Freeman HJ. Occult celiac disease in an octogenarian presenting with a small intestinal adenocarcinoma. Can J Gastroenterol 1994;8:354-7.

14. Hankey GL, Holmes GKT. Coeliac disease in the elderly. Gut 1994;35:65-7.

15. Wolber R, Owen D, DelBuono L, Appleman H, Freeman HJ. Lymphocytic gastritis in patients with celiac sprue or sprue-like intestinal disease. Gastroenterology 1990;98:310-5.

16. Wolber R, Owen D, Freeman HJ. Colonic lymphocytosis in patients with celiac sprue. Hum Pathol 1990;21:1092-6.

17. Freeman HJ, Weinstein WM, Shnitka TK, Wensel R, Sartor V. Watery diarrhea syndrome associated with a lesion of the colonic basement membrane lamina propria 
interface. Ann R Coll Phys Surg Can 1976;9:45.

18. Freeman HJ. Collagenous inflammatory mucosal disorders

of the gastrointestinal tract. Can J Gastroenterol 1990;4:196-200.

19. Freeman HJ, Whittaker JS. Nonalcoholic chronic pancreatitis with pancreatic calcification: presenting manifestation of occult celiac disease. Can J Gastroenterol 1994;8:319-22.

20. Freeman HJ. Occult celiac disease associated with lymphocytic sclerosing cholangitis. Can J Gastroenterol 1994;8:249-52.

21. Branski D, Ashkenazi A, Freier S, et al. Extraintestinal manifestations and associated disorders of celiac disease. Front Gastrointest Res 1992;19:164-75.

22. Swinson CM, Slavin G, Coles EC, Booth CC. Coeliac disease and malignancy. Lancet 1983;i:112-7.

23. Cooke WT, Holmes GKT. Malignancy. In: Coeliac Disease. Edinburgh: Churchill Livingstone, 1984:172-96
24. Pauzner R, Rothman P, Schwartz E, et al. Acute onset of celiac disease in the puerperium. Am J Gastroenterol 1992;87:1037-9.

25. Erdozain JC, de Argila CM, Cerezo E, Lizasoain J, Presa M. Adult celiac disease: reactivation during pregnancy and puerperium. Am J Gastroenterol 1993;88:1139-40.

26. Cooper BT, Holmes GKT, Cooke WT. Lymphoma risk in coeliac disease of later life. Digestion 1982;23:89-92. 


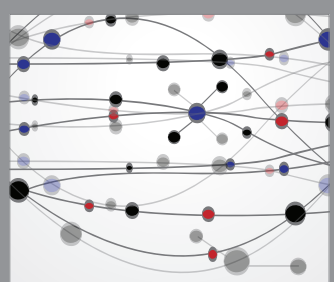

The Scientific World Journal
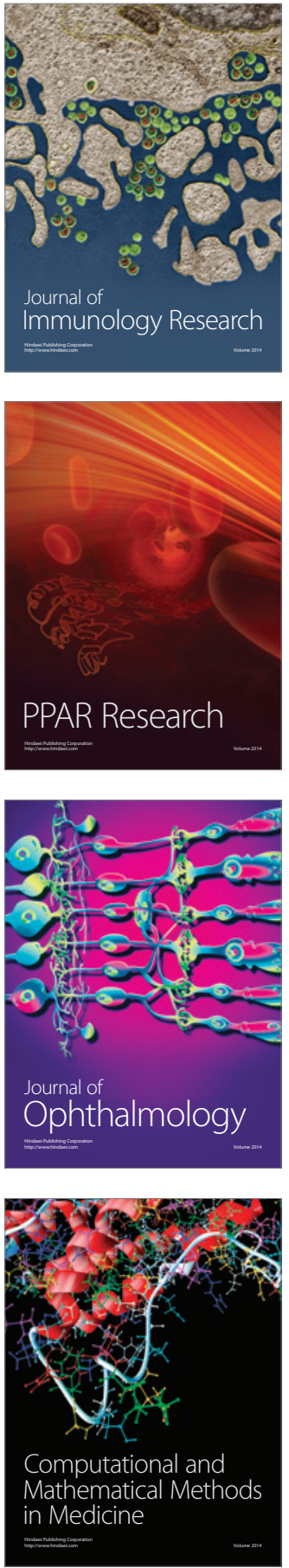

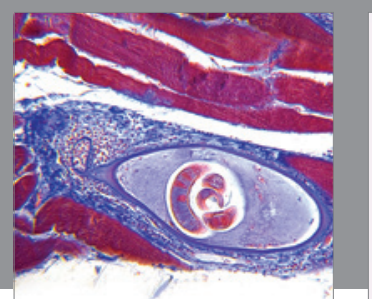

Gastroenterology Research and Practice

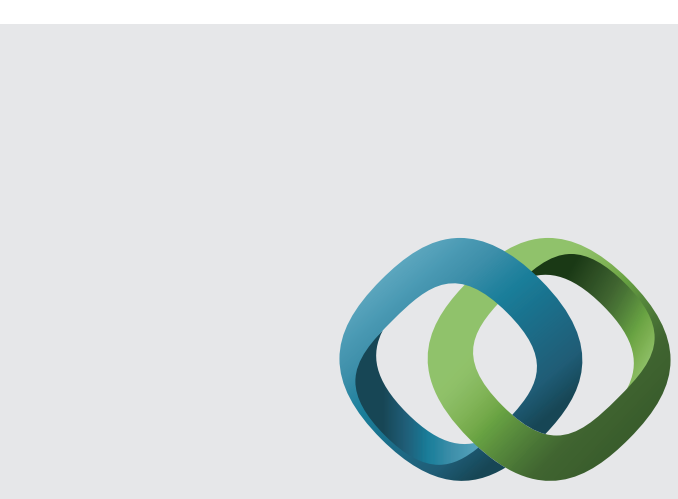

\section{Hindawi}

Submit your manuscripts at

http://www.hindawi.com
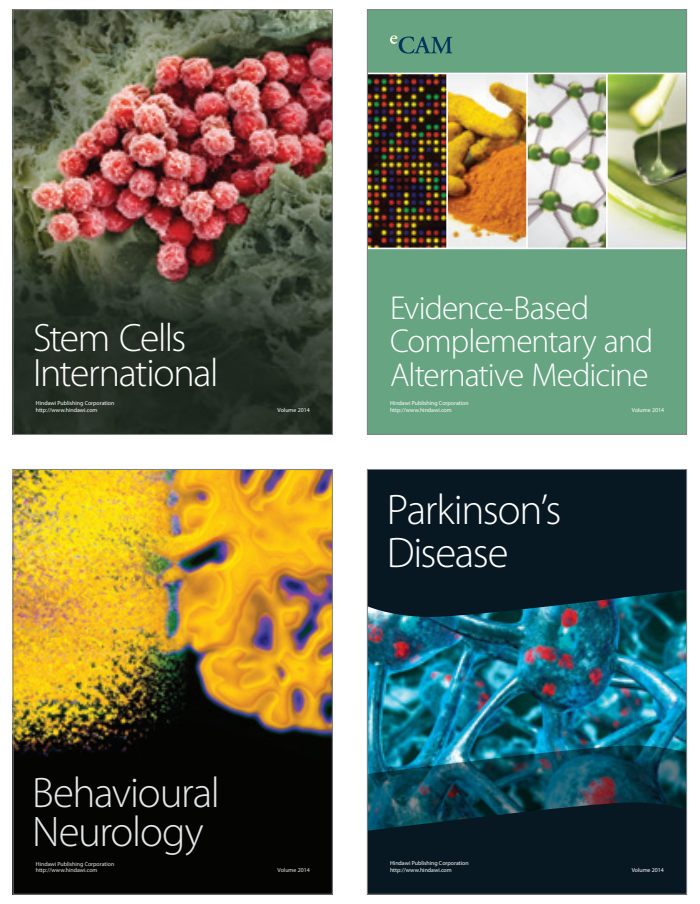
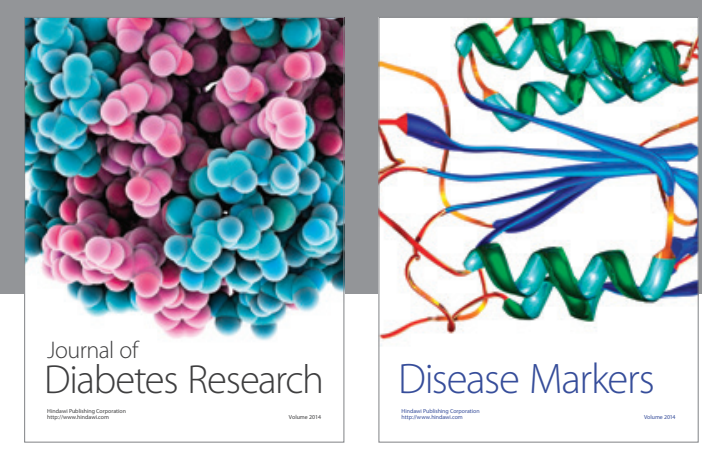

Disease Markers
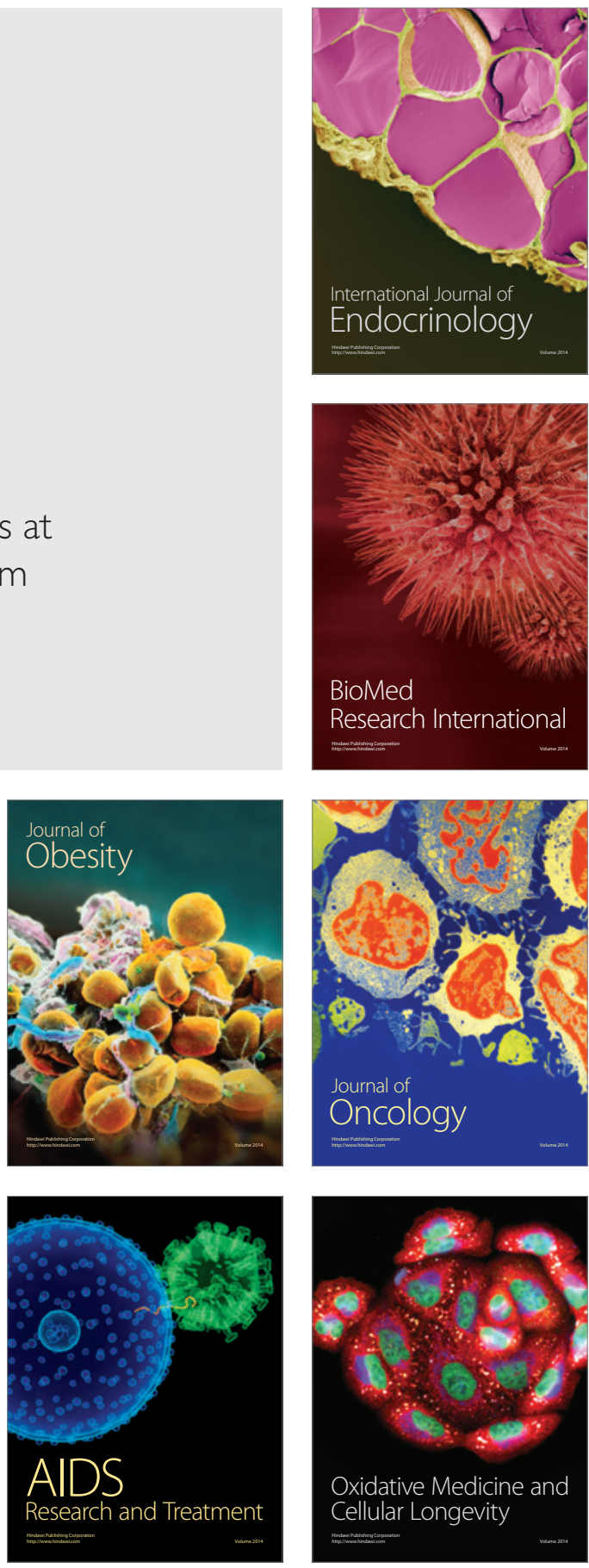